\title{
GRAPHOLOGY AS A HUMAN RESOURCES SELECTION TOOL IN THE ORGANISATIONS
}

\author{
Maja Panova ${ }^{1}$ \\ GSUC,AArseni Jovkov”-Skopje, R. Macedonia \\ Kiril Postolov ${ }^{2}$ \\ University „Cyril and Methodius”, Faculty of Economics,Skopje, R. \\ Macedonia
}

\begin{abstract}
The graphology is a quasi-science (pseudo-science). It is considered to be one of the unconventional methods for human resources selection in the organizations. The graphologists believe that on the base of the handwriting and on the written material a psychologic personal's profile can be made. With the graphological analyses numerous features of the handwriting can be interpreted such as: the initial and final of one word' emphasis, correctness and readability of the words, letter' s form, letter's size, hand pressure on the paper, distance between the lines, writings course and other. This method is not scientifically approved, although it is used in the organizations in a lot of West European countries and in USA as a tool for selection of human resources. In the most of the announces for vacancies the candidates are required to fulfill the application forms in hand.
\end{abstract}

Keywords: graphology, graphological analyse, human resources selection tool, graphologists

\section{GRAPHOLOGY}

\section{INTRODUCTION}

The graphology is a specific procedure for analysing and identification of the hand writing. Graphologists believe that on the base of the written material, taking into consideration triangles of the letters, the size and width of the letters, the hand pressure on the paper's sheet, the connection's style of the letters, the words correctness, the way of the writing and similar things can be made a psychical personality' s profile, to discover their disadvantages, advantages, attitudes, motives, interests, dispositions, ambitions, interest for the work and other features. This method is non scientifically approved and based on coincidence, guessing, hypotheses, but apart from these data its got a wide use in the West European countries and in USA. Especially it is popular in France where 75 до $80 \%$ from the small and middle enterprises use it for the selection of the human resources. (Smith, J. M., Abrahamsen, M. cited from Bahtijarevič - Šiber, F. s. 427)

\footnotetext{
1 E-mail: kiril.postolov@eccf.ukim.edu.mk

${ }^{2}$ E-mail: nnadja19@yahoo.com
} 
For the popularity of the graphology contributed:

- Trustness in the abilities of the graphologists

- Newspapers and the articles in the media

- $\quad$ Attractivness of the whole procedures

- Simplicity of the procedure

methods Imperfection of the other traditional selection's

- The economy of this selection's tool and similar.

A lot of researches have been made to retest the validity of the results gathered by the graphological's analyses, but all of them leaning to its unimportant role in the process of selection. Very often there is incorellation among the findings of the graphologists relating to the candidates appraisal.

In 1625 the Italian medicine professor at the university in Bologna Camillo Baldi published the first book, where the theoretical bases for the beginnings of the graphology were elaborated and appeared the first theory of the posssible connection of the writing with the personality. The term graphology is introduced 200 years later from the French clergyman Jean Hippolyte Michon who was engaged with the graphology and was collecting and appraising a thousands of handwritings. Helmut Ploog is one of the leading german graphologists and he cited that trough the handwriting we can get the following information: life aim, level, form, structure, transparency, vitality, dynamic, developments perspectives, intelligence, motivation, temperament, honesty, extraversion, team spirit, correctness, creativity and other. The people who write towards left are considered for introverted persons, shyly with a little self-confidence. A man who writes towards right is disposed towards the environment, could be unbridle and strong stepping forward. The well deliberate man is recognized by the strong connection of the letters. If the letters are positioned in isolation from each other indicate the unbalance and also the analytical competency of the writer. With the graphologicals' analysis numerous handwriting's features are interpreted: the initial and final emphasizing the word, correctness and readability of the letters, form of the letters, the size of the letters, the hand pressure on a paper's sheet, distance between lines, course of writing and other. The Interpretations are given with symbolical associations which are partially known from

\footnotetext{
${ }^{3}$ Цветковиђ, Н., Тасиђ, З., Стаменковиђ, С., Кулиђ, С. (2013). НЕКОНВЕНЦИОНАЛНИ МЕТОДИ СЕЛЕКЦИЈЕ КАНДИДАТА ЗА ПОСАО. Pravno-Ekonomski Pogledi br. 1. www.pepogledi.org/Arhiva/2013_01/05\%20Nebojsa\%20Cvetkovic,\%20Zoran\%20Tasic \%20Srecko\%20Stamenke 03.01.2014 s. 16-18
} 
the psycho physionomy: the letters towards up - intellect, spirit, towards down - instinct, towards left-internal, inside, towards right-exterior, outside etc. It is not a surprising fact that there are more than 200 empirical studies for graphology and besides this it is further considered as a quasi- science (pseudo-science). Significant connection between the graphological appraisals and the personality's tests is very rarely approved, the art of the graphological choice of the candidates consists of the laic explanation of the biography's contents.

Also the psychology of the names has its own application in the graphology. Every letter has its own meaning for example the letter Bknowledge, intellect, studies, theory, depth of the conscience. (Hoefler 2004) Especially favoured are the analyses of the prominent personalities, by which the appraisal is related towards their perceptions of the publicity. If according to the hand writing of Barack Obama discovered a big power for realizing, than it would be a proof of the quality of the graphology. Or according to Angelika Hoefler, whose name means truth, that would be an indicator that the psychology of the names is veritable. ${ }^{4}$

The big letters and the emphasizing of the big letters indicate the disposition for dominance and competitiveness. ${ }^{5}$

The word's graphology origin if from the Greek words урафюwrite and $\lambda$ oyo $\varsigma$-word, a science for the writing. (Pfanne 1961; Pokorny, 1968) It was developed by Ludwig Klages into one specific science. He is considered as father of the graphology who put the base for the further researches in the area of neurology in Germany. Rodolf Pophal published the most important results in the area of graphology.

In the 50 and 60 years the graphology was a facultative programme on the studies for psychology in Freiburg. In the year 1987 was grounded the first scientific graphological association and relating to the number of the graphologists, the graphology institutes dispose with about 200000 certified graphologists. In Great Britain the responsible persons for human resources are very sceptical according to the graphology as a science and for this testify also the data that $0,5-1 \%$ from the enterprises in Great Britain use it as a selection tool, in France this percentage is $70-80 \%$, and the same is the situation in Israel. (Hopper/Standford 1992) Today we distinguish deductive (observe the

\footnotetext{
${ }^{4}$ Kanning, U. (2010). Absurde Methoden der Psychodiagnostik. Schädeldeutung und Co. (Skeptiker 3/2010) www.gwup.org/infos/nachrichten?aktion=detail\&id=92 06.01 .2014 s. 7-9

${ }^{5}$ MBA Knowledge Base. Type of tests taken in the selection process. www.mbaknol.com/human-resource-management/type-of-tests-taken-in-the-selectonprocess/ 08.01.2014
}

Vol. 17, бpoj 1/2015, cmp. 147-156 
hand writing as an analogy to the human expressing) from the empirical graphology (character determination of the person). The subject of the graphology (hand writing and the character) base on the human behavior. (Doubrawa, 1978 s. 19)

\section{ELEMENTS OF A GRAPHOLOGICAL ANALYSIS}

The smallest elements who are researched by the graphologists are 10 resulting from the hand movements at the writing, hand pressure, space and the speed of writing. The writing's space consists of the hight (up/down/over/beneath), the width (right/left), the depth (towards the space and out of the space). (Müller 1984) The following table is one of the mostly used base for analysing (interpreting) and consists from 3 areas: movement, form and space. elements.

Individual features-graphic letters, word's and sentence's

Tab. 1.: Individual features

\begin{tabular}{|lll|}
\hline feature & explanation & Psychologic analogy \\
\hline letter's size & $\begin{array}{l}\text { measurement of } \\
\text { the short (small) } \\
\text { and long (big) } \\
\text { letters }\end{array}$ & \\
& self-confidence \\
\hline letter's width & $\begin{array}{l}\text { the distance } \\
\text { between the } \\
\text { letters }\end{array}$ & $\begin{array}{l}\text { type of the disposition towards } \\
\text { the environment }\end{array}$ \\
\hline $\begin{array}{l}\text { lengths' } \\
\text { partition }\end{array}$ & $\begin{array}{l}\text { the relation } \\
\text { between the } \\
\text { upper lengths and } \\
\text { the under lengths }\end{array}$ & $\begin{array}{l}\text { orientation between ,intellect",matter" } \\
\text { and , }\end{array}$ \\
\hline difference in & $\begin{array}{l}\text { the relationship } \\
\text { between the long } \\
\text { the length }\end{array}$ & relationship towards the tasks \\
& $\begin{array}{l}\text { short (small) } \\
\text { sized letters }\end{array}$ & \\
\hline connections & $\begin{array}{l}\text { connections } \\
\text { forms f .e dashes } \\
\text { form }\end{array}$ & $\begin{array}{l}\text { type of disposition towards the } \\
\text { environment }\end{array}$ \\
\hline $\begin{array}{l}\text { connection's } \\
\text { degree }\end{array}$ & $\begin{array}{l}\text { the level of } \\
\text { relationship's } \\
\text { emphasis } \\
\text { between the } \\
\text { letters }\end{array}$ & $\begin{array}{l}\text { type of the thinking(intuitive, } \\
\text { logical) }\end{array}$ \\
\hline $\begin{array}{l}\text { plight of the hand } \\
\text { writing from the } \\
\text { view of an angle }\end{array}$ & $\begin{array}{l}\text { type of the contacts to the } \\
\text { environment } \\
\text { (disposition/indisposition) }\end{array}$ \\
\hline
\end{tabular}


Graphology as a human resources selection tool in the organization

\begin{tabular}{|c|c|c|}
\hline \multicolumn{3}{|c|}{ from $180^{\circ}$} \\
\hline $\begin{array}{l}\text { distance } \\
\text { between the } \\
\text { words }\end{array}$ & $\begin{array}{l}\text { space between the } \\
\text { words }\end{array}$ & $\begin{array}{l}\text { pulling the intellectual and } \\
\text { spiritual processes a part }\end{array}$ \\
\hline $\begin{array}{l}\text { distance } \\
\text { between the } \\
\text { lines }\end{array}$ & $\begin{array}{l}\text { space between the } \\
\text { lines }\end{array}$ & type of control \\
\hline $\begin{array}{l}\text { introduction } \\
\text { of the lines }\end{array}$ & $\begin{array}{l}\text { direction and } \\
\text { form of the lines }\end{array}$ & mood and a feeling for the life \\
\hline $\begin{array}{l}\text { hand } \\
\text { writing's } \\
\text { margins }\end{array}$ & $\begin{array}{l}\text { left/right margin, } \\
\text { upper/under }\end{array}$ & $\begin{array}{l}\text { handling some life situation } \\
\text { (care-free manner, } \\
\text { cautiousness) }\end{array}$ \\
\hline $\begin{array}{l}\text { emphasize of } \\
\text { the beginning }\end{array}$ & $\begin{array}{l}\text { emphasize } \\
\text { (enlargement, } \\
\text { strength of the } \\
\text { hand pressure, } \\
\text { designing) of the } \\
\text { initial letters }\end{array}$ & level of self-confidence \\
\hline $\begin{array}{l}\text { emphasize of } \\
\text { the end }\end{array}$ & $\begin{array}{l}\text { emphasize } \\
\text { (enlargement, } \\
\text { strength of the } \\
\text { hand pressure, } \\
\text { designing) of the } \\
\text { end letters }\end{array}$ & $\begin{array}{l}\text { type of immediate influence on } \\
\text { the environment (passive } \\
\text { restraint/try for realizing) }\end{array}$ \\
\hline
\end{tabular}

Adopted according to (source-Pokorny 1968; Dirks 1974) cited in Domsch, M. E ,

Ladwig*, A. Die Außenseiterrolle der Graphologie in der Personalauswahl. Eine

Bestandsaufnahme** (ZfP 3/96) www.hampp-verlag.de/Archiv/3_96_Domsch.pdf

$$
\text { s. } 249
$$

Preconditions for a good graphologic analysis:

the written material should consist of about 10 lines

or it should be 2-3 written materials of different periods

the writing should result spontaneous

$>\quad$ the writing should be in the mother tongue

$>\quad$ the writing should be on a white paper' sheet

without lines (it is recommended to result by a pan )

$>\quad$ the person's signature is also valuable

$>\quad$ the person' data who could be useful for the

graphologist are the following: profession, sex, age, the country of provenience, as well as if the person is right-handed or lefthanded.

In the graphology there are 2 observation's areas:

psychological

$$
\text { graphological }
$$


The procedure in the both areas is based on analysis and synthesis. For the serious graphologists it is necessarry to get before the candidate's selection a defined required candidate's profile.

Tab. 2.: Individual features of higher complexity

\begin{tabular}{|c|c|c|}
\hline feature & explanation & Psychological analogy \\
\hline neatness & $\begin{array}{l}\text { inconsistency of } \\
\text { the features, } \\
\text { especially of the } \\
\text { size, brightness } \\
\text { from the view of } \\
\text { the neatness }\end{array}$ & $\begin{array}{l}\text { preparedness/ability, rule's } \\
\text { acceptions }\end{array}$ \\
\hline $\begin{array}{l}\text { form's } \\
\text { reachness }\end{array}$ & $\begin{array}{l}\text { emphasis degree } \\
\text { and/or hand } \\
\text { writing's } \\
\text { integrity }\end{array}$ & $\begin{array}{l}\text { subject-matter's peculiarity of } \\
\text { the experience and peculiarity } \\
\text { of the thinking } \\
\text { (awake, imaginative) }\end{array}$ \\
\hline $\begin{array}{l}\text { form } \\
\text { consistency }\end{array}$ & $\begin{array}{l}\text { form's stability } \\
\text { and symmetry }\end{array}$ & $\begin{array}{l}\text { personality's structure } \\
\text { (teased, leisure) }\end{array}$ \\
\hline $\begin{array}{l}\text { introduction } \\
\text { of dashes }\end{array}$ & $\begin{array}{l}\text { expression of the } \\
\text { movements and } \\
\text { of the rhythm } \\
\text { (stiff, sluggish, } \\
\text { swinging and } \\
\text { similar) }\end{array}$ & $\begin{array}{l}\text { type of psychic development } \\
\text { (free/prevented experience) }\end{array}$ \\
\hline $\begin{array}{l}\text { the writing's } \\
\text { pressure of } \\
\text { dashes }\end{array}$ & $\begin{array}{l}\text { force applying at } \\
\text { pressure on the } \\
\text { paper }\end{array}$ & $\begin{array}{l}\text { intensity of psychic } \\
\text { development } \\
\text { (feeling, seeking) }\end{array}$ \\
\hline $\begin{array}{l}\text { writing' } s \\
\text { speed }\end{array}$ & $\begin{array}{l}\text { time needed of } \\
\text { one word writing }\end{array}$ & $\begin{array}{l}\text { intensity of psychic experience } \\
\text { (thoughts, feelings, seeking) }\end{array}$ \\
\hline
\end{tabular}

Adopted according to (source -Müller/Enskat 1973; Pokorny 1968;Dirks1974) citted in

Domsch, M. E, Ladwig*, A. Die Außenseiterrolle der Graphologie in der

Personalauswahl. Eine Bestandsaufnahme**(ZfP 3/96) www.hamppverlag.de/Archiv/3 96_Domsch.pdf s. 250

\section{ARGUMENTS AND CONTRA ARGUMENTS ABOUT THE GRAPHOLOGY}

Arguments which approve the use of the graphology as a human resource's selection tool are following:

- the written material is not a test

- the candidate should not be present, how is the case with the another tests

- There is a necessity of a written materialcandidate's hand writing 
- External appraisal, as well as reducing of the direct contact in the relation candidate-enterprise.

- $\quad$ Economy f.e one graphologic appraisal costs 225 \$ according to Hopper/Stanford (1992)

understandable

The appraisal should be formulated clearly and

- The validity is not lower than the validity of the another more expensive tools

- The graphologic appraisal has a priority in the case when is required a second opinion

- The graphologic appraisal starts regarding more criteria f.e (trustfullness, preparedness for cooperation, workability etc.)

Factors which influence the hand writing are following: the needed time, the writing tool, the cause of writing, the contents, the physical and psychical person's condition.

Some of the contra arguments against the use of the graphology as a human resources selection tool are the following :

* Handwriting's changeability

* The candidate's absence (it could be not a guarantee that it is talked about the same candidate)

* According to one empirical study the handwriting's contents has a little influence on the graphologic appraisal, only the graphologists's abilities are influencing the appraisal

* The objectivity of the graphologics appraisal have a coefficient of 0,97 (Lücke /Baer 1989, Fischer 1964; Seibt 1994)

* The reliability is $(\mathrm{r}=0,8-0,93)$ in one re-test period of one week. (Fischer 1964)

In 80 and 90 years Halder -Sinn (1989) in one research of 400 newspaper articles was found that in 20 announces for vacancies it was required to fulfill applications forms in hand. According to another analysis on 9766 vacancies in 4 newspapers as the following Hamburger Abendblatt, Frankfurter Allgemeine Zeitung, Süddeutsche Zeitung, die Welt in a period from 1 to 4 weeks was discovered that fulfilled application forms in hand of the candidates were required. According to the analyses it was selected for the following positions: senior managers, junior managers, practitioners and professional employees. The graphology is also used for the aims of development i.e for appraisal of the developments potentials of the employees in the organization. ${ }^{6}$

\footnotetext{
${ }^{6}$ Domsch, M. E, Ladwig*, A. Die Außenseiterrolle der Graphologie in der Personalauswahl. Eine Bestandsaufnahme** (ZfP 3/96) www.hamppverlag.de/Archiv/3_96_Domsch.pdf 06.01.2014 s.241-262
} 
It is considered that the graphological handwriting's analysis from the view of the interpretation have similarity to the proactive personality's tests.

This method was a lot of used in the West Europe in the last 40 years and also it is used in USA in the most of the companies as a human resources selection' $s$ tool and this mostly for the fulfillment of the strategic positions. Beside of all its validity is small and it can not provide for the work success. ${ }^{7}$ As George Bohlander and Scott Snell have cited in "Managing Human Resources" 15 th.ed the companies Ford and General Electric have used the graphologic's hand writings analyses for the choice of the new employees. According to their citations some of the American courts have concluded that the hand writing's analysis can be used as detecting tool if some hand writing is fake or original, but not for identification of the psychological and work features of a person.

The psychological researches have showed that the graphology can not appraise the humans personality. ${ }^{8}$

According to them it doesn't have prognostic validity and because of this could not be treated as a serious human resource's selection tool. The disagreement of the graphologists in their analysis support this findings. But however besides of all finds it is further used in $80 \%$ of the companies in West Europe.'

One study of Clark (1993) showed that $13,3 \%$ of the consulting firms in Germany for manager's recruitment have used grafologics analyses in their candidate's choice, while in some other countries from the view of its use the situation is following in France 47,8\%, Italy 6,3\% and Great Britain 2,6\%. ${ }^{10}$

\footnotetext{
${ }^{7}$ Станкоска, М. (2010). Избор на најдобри кандидати во организащијата преку процес на регрутащија и селекција. маг., Универзитет "Св.Кирил и Методиј”, Економски факултет , Скопје. с. 143

${ }^{8}$ Suša , B. (2009). Menadžment ljudskih resursa. 1 izd. „CEKOM”-books d.o.o, Novi Sad, s. 218

${ }^{9}$ urlj skripta, nova-Seminarski Maturski Diplomski Rad www.maturski.net/fakultet-zakulturu-i-medije/urlj-skripta-nova 20.12.2013 s.26

${ }^{10}$ Rastetter, D. (1996). Personalmarketing,Bewerberauswahl und Arbeitsplatzsuche. Ferdinand Enke Verlag, Basistexte Personalwesen herausgegeben von Neuberger, O., Stuttgart www.wiso.unihamburg.de/fileadmin/sozialoekonomie/bwl/fachgebiet/Rast._Buch/buch.pdf 06.01.2014 s. 243
} 


\section{CONCLUSION}

The graphology is used in the companies in USA and the West European countries as one of the tools for human resources selection. In some of them there are graphological centers and their appraisements are used especially in the aim of the candidate's choice for fulfillment the managerial positions. It seems that the persons believe in the graphologist's knowledge and their ability of hand writing's interpretations. Maybe in our country there will be an interest for its study and graphologists, who will be able to do graphological analysis which will make possible use of the graphology as one of the human resources selection tool to fulfill the vacancies in the organizations. Because it is an economic selection's tool and also interesting for use. Imperfection of the traditional selection's methods is a stimulation for the organizations to turn themselves to a bit different and unusual selection's methods as the graphology. The more brighter use of the tablets in the everyday activities, which have a capacity and possibility for data' writing into it opens also a new space for additional development in the area of the graphological handwriting's analyses.

\section{LITERATURE}

1. Цветковиђ, Н., Тасиђ, З., Стаменковиђ, С., Кулиђ, С. (2013). НЕКОНВЕНЦИОНАЛНИ МЕТОДИ СЕЛЕКЦИЈЕ КАНДИДАТА ЗА ПОСАО. Pravno-Ekonomski Pogledi br.1. www.pepogledi.org/Arhiva/2013_01/05\%20Nebojsa\%20Cvetkovic, \% 20Zoran\%20Tasic,\%20Srecko\%20Stamenke 03.01.2014

2. Domsch, M. E, Ladwig*, A. Die Außenseiterrolle der Graphologie in der Personalauswahl. Eine Bestandsaufnahme**. (ZfP 3/96) www.hampp-verlag.de/Archiv/3_96_Domsch.pdf 06.01.2014

3. Kanning, U. (2010). Absurde Methoden der Psychodiagnostik, Schädeldeutung und Co.

(Skeptiker 3/2010)

www.gwup.org/infos/nachrichten?aktion=detail\&id=92 06.01.2014

4. Rastetter, D. (1996). Personalmarketing, Bewerberauswal und Arbeitsplatzsuche. Ferdinand Enke Verlag, Basistexte Personalwesen herausgegeben von Neuberger, O. , Stuttgart www.wiso.unihamburg.de/fileadmin/sozialoekonomie/bwl/fachgebiet/ Rast._Buch/buch.pdf 06.01.2014 
5. Станкоска, М. (2010). Избор на најдобри кандидати во организацијата преку процес на регрутаџија и селекција. маг., Универзитет "Св.Кирил и Методиј”, Економски факултет, Скопје. 6. Suša, B. (2009). Menadžment ljudskih resursa. 1 izd., „CEKOM”books d.o.o, Novi Sad

7. MBA Knowledge Base. Type of tests taken in the selection process. www.mbaknol.com/human-resource-management/type-oftests-taken-in-the-selecton-process/ 08.01.2014 8. urlj skripta, nova-Seminarski Maturski Diplomski Rad www.maturski.net/fakultet-za-kulturu-i-medije/urlj-skripta-nova 20.12.2013 